\title{
VARIABEL-VARIABEL YANG MEMPENGARUHI TINGKAT BAGI HASIL TABUNGAN MUDHARABAH PADA INDUSTRI PERBANKAN SYARIAH DI INDONESIA PERIODE 2011-2014 1)
}

\author{
Lauda Huruniang \\ Mahasiswa Program Studi S1 Ekonomi Islam-Fakultas Ekonomi dan Bisnis-Universitas Airlangga \\ Email : laudahuruniang@gmail.com
}

Noven Suprayogi

Departemen Ekonomi Syariah-Fakultas Ekonomi dan Bisnis-Universitas Airlangga

Email : noven.suprayogi@feb.unair.ac.id

\begin{abstract}
:
The purpose of this research is examine the influence of non performing financing (NPF), financing to deposit ratio (FDR), total revenue, and $\mathrm{Bl}$ rate toward trustee profit sharing mudharabah Islamic Bank Industries in Indonesia start from January 2011 until June 2014 periods. This research uses quantitative approach. The analysis method used in this research is the method of multiple linear regression analysis of time series with a significance level of 0,05 .

The result showed that performing financing (NPF) and BI rate have significant influence toward trustee profit sharing mudharabah partially, while financing to deposit ratio (FDR) and total revenue does not influence trustee profit sharing mudharabah significantly. However, non performing financing (NPF), financing to deposit Ratio (FDR), total revenue, and BI rate have significant influence toward trustee profit sharing mudharabah simultaneously.

Keywords : Non Performing Financing (NPF), Financing to Deposit Ratio (FDR), Total Revenue, BI rate, Trustee Profit Sharing Mudharabah
\end{abstract}

I. PENDAHULUAN

Latar Belakang

Ditengah kondisi perekonomian Indonesia yang saat ini masih dalam tahap pemulihan, pertumbuhan perbankan syariah di Indonesia saat ini berkembang dengan pesat. Perbankan Syariah merupakan bagian dari salah satu industri keuangan syariah dengan menggunakan prinsip-prinsip Ekonomi Islam. Menurut Machmud dan Rukmana (2010 : 9) bank syariah disebut juga dengan bank yang tidak menetapkan bunga tetapi berdasarkan prinsip bagi hasil. Prinsip bunga dalam Islam sangat dilarang. Hal ini sesuai dengan Alquran dalam Qs. Ali Imran ayat 130 sebagai berikut :

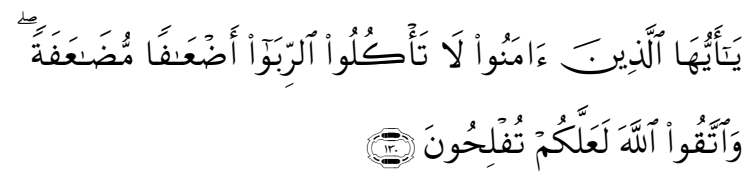

Yā ayyuhal-lażīna āmanū lā ta'kulur-riba aḍ' āfamuḍ' afah(tan), wattaqullāha la'allakum tuflihūn.

Artinya: "Hai orang-orang yang beriman, janganlah kamu memakan Riba dengan berlipat ganda dan bertakwalah kamu kepada Allah supaya kamu mendapat keberuntungan." (Departemen Agama RI, $2010: 66)$

Hal yang sama bahwa riba dilarang dapat dilihat pada Hadits berikut ini :

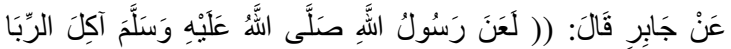

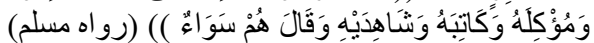

'an jābirin qāla : la'ana rasulullāhi shola allāh 'alaihi wa salama akilurriba wa 1) Jurnal ini merupakan bagian dari Skripsi yang ditulis oleh (Lauda Huruniang; NIM : 041114157 ), yang diuji pada tanggal 22 Juni 2015 
mu'kilahu wa kātibahu wa syahidahi wa qālahum sawā' un.

Dari Jabir ra berkata, bahwa Rasulullah SAW melaknat orang yang memakan riba, orang yang memberikannya, penulisnya dan dua saksinya, dan beliau berkata, mereka semua adalah sama (HR. Muslim no.2995, Kitab al-Masaqqah).

Pada umunya perbankan syariah di Indonesia beroperasi dengan prinsip bagi hasil antara nasabah dengan bank syariah. Manfaat adanya bagi hasil adalah baik nasabah atau bank syariah memperoleh kepuasan, memberikan manfaat keadilan yang diterima oleh nasabah dan bank syariah. Perhitungan bagi hasil pada perbankan syariah di Indonesia berdasarkan profit yang diperoleh (profit and loss sharing) yang didasarkan kepada revenue sharing (yang dibagikan pendapatannya).

Nasabah sebagai shahibul maal menyimpan vang di bank syariah dengan tujuan sebagai pemilik dana yang melakukan investasi pada bank syariah. Bank syariah sebagai mudharib bertugas untuk mengelola dana yang diperoleh dari nasabah. Di akhir perjanjiannya, keuntungan tersebut akan dibagihasilkan sesuai dengan kesepakatan antara nasabah dan bank syariah. Besarnya tingkat keuntungan yang diterima oleh nasabah disebut dengan tingkat bagi hasil.

Penentuan tingkat bagi hasil adalah hal paling utama untuk mendapatkan bagi hasil yang diterima oleh nasabah. Tingkat bagi hasil
Perbankan Syariah di Indonesia dapat dilihat dalam tabel 1.2

Tabel 1.

Tingkat bagi Hasil Dana Pihak Ketiga pada Perbankan Syariah di Indonesia

Tahun 201 1-Juni 2014 (dalam satuan \%)

\begin{tabular}{|c|c|c|c|c|}
\hline Indikator & 2011 & 2012 & $\begin{array}{l}2013 \\
\text { (Juni) }\end{array}$ & $\begin{array}{l}2014 \\
\text { (Juni) }\end{array}$ \\
\hline Tabungan iB & 3,21 & 2,37 & 5,35 & 5,76 \\
\hline \multicolumn{5}{|l|}{ Deposito iB } \\
\hline a. 1 Bulan & 6,90 & 6,06 & 4,77 & 5,49 \\
\hline b. 3 Bulan & 6,68 & 6,17 & 4,86 & 6,10 \\
\hline c. 6 Bulan & 7,15 & 6,76 & 6,04 & 6,09 \\
\hline d. 12 Bulan & 7,32 & 6,27 & 6,16 & 5,80 \\
\hline $\begin{array}{lll}\text { e. } & > & 12 \\
& \text { Bulan }\end{array}$ & $\begin{array}{r}48,1 \\
4\end{array}$ & 6,49 & 5,42 & 6,65 \\
\hline
\end{tabular}

Sumber : Statistik Perbankan Syariah (SPS), Juni 2014 (diolah)

Dari data di atas diperoleh bahwa tingkat bagi hasil tabungan mudharabah dari tahun 2011 mengalami penurunan sebesar $2,37 \%$ dan mengalami peningkatan pada tahun 2013 sebesar $5,35 \%$ dan $5,76 \%$, sedangkan tingkat bagi hasil pada deposito pada tahun 2011 ke tahun 2012 dan 2013 mengalami penurunan. Sedangkan pada tahun 2014 mengalami kenaikan lagi. Hal ini dikarenakan ada beberapa faktor yang mempengaruhi kenaikan atau penurunan tingkat bagi hasil tersebut. Penelitian ini berusaha mencari faktor-faktor yang mempengaruhi tingkat bagi hasil khususnya pada tabungan mudharabah.

Pengaruh langsung dari investasi yang dilakukan oleh bank syariah adalah bagi hasil yang diterima oleh nasabah. 
Pendapatan yang akan dibagihasilkan bergantung kepada kualitas penyaluran dana. Semakin baik kualitas penyaluran dana maka akan semakin besar dana yang akan diterima oleh bank syariah. Kesalahan dalam penyaluran dana kepada investor untuk mendapatkan bagi hasil yang maksimal, akan menimbulkan kredit macet yang ditunjukkan oleh NPF (Non Performing Financing). Apabila NPF tinggi, maka return yang diterima nasabah akan menurun. Menurut Antonio (2001 : 145) bahwa bank syariah memberikan tingkat bagi hasil kepada nasabah dengan menggunakan pendekatan FDR. Antonio (2001 : 145) juga menjelaskan bahwa besar kecilnya bagi hasil yang diperoleh dalam kontrak mudharabah salah satunya adalah bergantung kepada pendapatan bank syariah. $\mathrm{BI}$ rate memiliki pengaruh terhadap investasi yang berpengaruh kepada perolehan bagi hasil nasabahnya.

Oleh karena itu perlu diteliti
seberapa besar "pengaruh non
performing financing (NPF), financing to deposit ratio (FDR), total pendapatan, dan BI rate terhadap tingkat bagi hasil tabungan mudharabah industri perbankan syariah di Indonesia periode 2011-2014".

\section{Rumusan Masalah}

Berdasarkan uraian latar belakang diatas, maka rumusan masalah yang diajukan dalam penelitian ini adalah apakah Non Performing Financing (NPF), Financing to Deposit Ratio (FDR), Total
Pendapatan, dan $\mathrm{Bl}$ rate secara parsial dan simultan berpengaruh terhadap Tingkat Bagi Hasil Tabungan Mudharabah Industri Perbankan Syariah di Indonesia periode 2011-2014?

\section{Tujuan Penelitian}

Berdasarkan rumusan masalah diatas, maka tujuan penelitian ini adalah untuk mengetahui pengaruh Non Performing Financing (NPF), Financing to Deposit Ratio (FDR), Total Pendapatan, dan $\mathrm{Bl}$ rate secara parsial dan simultan terhadap Tingkat Bagi Hasil Tabungan Mudharabah Industri Perbankan Syariah di Indonesia periode 2011-2014

\section{LANDASAN TEORI \\ PENGEMBANGAN HIPOTESIS}

DAN

\section{Bank Syariah}

Secara umum, Bank syariah adalah lembaga keuangan yang usaha pokoknya memberikan kredit dan jasajasa lain dalam lalu lintas pembayaran serta peredaran vang yang beroperasi yang disesuaikan dengan prinsi-prinsip syariah (Sudarsono, 2008 : 29). Menurut pembukaan standar akuntansi oleh Accounting an Auditing Organizing for Islamic Financial Institution (AAOIFI), bahwa fungsi dan peran bank syariah adalah manajer investasi, investor, penyedia jasa keuangan dan lalu lintas pembayaran, dan pelaksanaan kegiatan sosial. (Sudarsono, $2008:$ 45)

Hubungan antara Non Performing Financing (NPF) terhadap Tingkat Bagi Hasil Nasabah pada Tabungan

\section{Mudharabah}


Menurut Djamil (2014 : 72) berpendapat bahwa penyebab dari pembiayaan bermasalah salah satunya adalah bagi hasil. Wiroso (2005: 60) juga berpendapat bahwa Non performing financing (NPF) akan berdampak pada menurunnya tingkat bagi hasil yang dibagikan pada pemilik dana. Menurut Mawardi (2005) bahwa apabila NPF tinggi, maka return yang diterima nasabah akan menurun. Sehingga nasabah mengalihkan tabungannya kepada bank lain yang mempunyai tingkat bagi hasil yang tinggi. Hal ini dapat disimpulkan apabila NPF naik maka tingkat bagi hasil yang diberikan ke nasabah akan mengalami penurunan.

\section{Hubungan antara Financing to Deposit Ratio (FDR) terhadap Tingkat Bagi Hasil Nasabah pada Tabungan Mudharabah}

Kondisi internal bank syariah bergantung kepada dana pihak ketiga. Dana pihak ketiga merupakan salah satu faktor untuk menentukan bagi hasil (Antonio, 2001 : 139). Salah satu ketentuan yang dipakai untuk menentukan perolehan jumlah dana pihak ketiga adalah dengan FDR (Financing to Deposit Ratio). FDR adalah ratio antara dana yang ditempatkan pada pembiayaan dibandingkan dengan dana yang dihimpun dari masyarakat atau dana pihak ketiga. Menurut Vustany (2006) menjelaskan bahwa dana untuk pembiayaan yang akan disalurkan sebanding dengan jumlah dana pihak ketiga. Pertumbuhan dana pihak ketiga yang tinggi memberikan bagi hasil yang tinggi kepada nasabahnya. Semakin besar dana pihak ketiga maka FDR juga semakin besar. Maka dari pernyataan tersebut dapat disimpulkan bahwa apabila FDR tinggi maka tingkat bagi hasil juga tinggi.

\section{Hubungan antara Total Pendapatan terhadap Tingkat Bagi Hasil Nasabah pada Tabungan Mudharabah}

$$
\text { Menurut Arifin (2009: 70) }
$$

menerangkan bahwa berdasarkan asumsi nasabah bank syariah belum terbiasa menerima kondisi berbagi hasil dan berbagi risiko, maka bank syariah di Indonesia menggunakan sistem revenue sharing. Revenue sharing diperoleh melalui bagi hasil yang didistribusikan dihitung dari total pendapatan bank sebelum dikurangi dengan biaya bank syariah. Hal ini didukung oleh pernyataan Muhamad (2004 : 98) bahwa bank yang menggunakan sistem revenue sharing memiliki tingkat bagi hasil yang diterima oleh pemilik dana akan lebih besar daripada tingkat suku bunga pasar yang berlaku. Antonio (2001: 145) juga menjelaskan bahwa besar kecilnya bagi hasil yang diperoleh dalam kontrak mudharabah salah satunya adalah bergantung kepada pendapatan bank syariah.

\section{Hubungan Antara BI rate terhadap Tingkat} Bagi Hasil Nasabah pada Tabungan Mudharabah

Menurut Bank Indonesia pengertian dari BI rate adalah suku bunga kebijakan yang mencerminkan sikap atau 
stance kebijakan moneter yang ditetapkan oleh bank Indonesia dan diumumkan kepada publik. Menurut Vustany (2006) bahwa variabel BI rate mempunyai pengaruh terhadap iklim investasi yang berpengaruh kepada perolehan bagi hasil nasabah. Apabila BI rate turun, maka tingkat bagi hasil mengalami kenaikan.

\section{Hipotesis}

Berdasarkan teori dan konsep dalam rumusan masalah, tujuan, dan landasan teori, maka hipotesis dalam penelitian dirumuskan sebagai berikut :

1. Non Performing Financing (NPF), Financing to Deposit Ratio (FDR) dan Total Pendapatan, dan BI Rate secara parsial berpengaruh terhadap Tingkat Bagi Hasil Tabungan Mudharabah Industri Perbankan Syariah di Indonesia periode 2011-2014.

2. Non Performing Financing (NPF), Financing to Deposit Ratio (FDR) dan Total Pendapatan, dan BI Rate secara simultan berpengaruh terhadap Tingkat Bagi Hasil Tabungan Mudharabah Industri Perbankan Syariah di Indonesia periode 20112014.

\section{Model Analisis}

Model analisis adalah sebagai berikut :

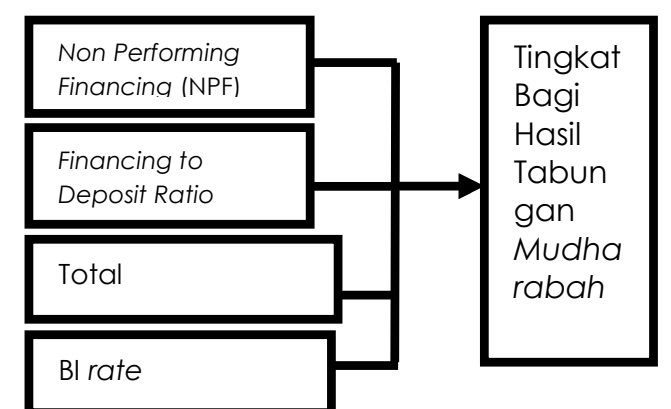

Sumber: Penelitian, 2015

Gambar 1.

Model Analisis secara Parsial dan Simultan

Persamaan regresi linear berganda dalam penelitian ini sebagai berikut :

$Y=a+b_{1} X_{1}+b_{1} X_{2}+b_{1} X_{3}+b_{1} X_{4}+€$

Keterarangan :

$Y=$ Tingkat bagi hasil nasabah

$a=$ Konstanta

$b_{1}=$ Koefisien regresi

$X_{1}=$ Non Performing Financing (FDR)

$X_{2}=$ Financing to Deposit Ratio (FDR)

$X_{3}=$ Total pendapatan

$\mathrm{X}_{4}=\mathrm{BI}$ Rate

$€=$ error

\section{METODE PENELITIAN}

\section{Pendekatan Penelitian}

Penelitian ini menggunakan pendekatan kuantitatif dengan menggunakan hubungan kausal atau mempunyai hubungan sebab akibat dan bebas nilai.

\section{Identifikasi Variabel Penelitian}

1. Variabel Bebas atau Independent Variable $(\mathrm{X})$

$X_{1}=$ Non Performing Financing (NPF)

$X_{2}=$ Financing to Deposit Ratio (FDR)

$X_{3}=$ Total Pendapatan

$\mathrm{X}_{4}=\mathrm{B} \mid$ rate

2. Variabel Bergantung atau Dependent Variable

$Y=$ Tingkat bagi hasil tabungan mudharabah

\section{Definisi Operasional Variabel}

Definisi operasional variabel-variabel yang digunakan dalam penelitian ini adalah : 
1. NPF (Non Performing Financing) $\left(X_{1}\right)$ NPF adalah ratio antara pembiayaan bermasalah dengan total pembiayaan yang disalurkan oleh bank syariah. NPF dirumuskan sebagai berikut :

$\mathrm{NPF}=\frac{\text { Pembiayaan Bermasalah }}{\text { Total Pembiayaan }} \times 100 \%$

2. FDR (Financing to Deposit Ratio) $\left(\mathrm{X}_{2}\right)$ FDR adalah ratio antara dana yang ditempatkan pada pembiaaan dibandingkan dengan dana yang dihimpun dari masyarakat atau dana pihak ketiga. FDR dirumuskan sebagai berikut :

$$
F D R=\frac{j \text { wamlah pembiayaan }}{\text { total } D P K} \times 100 \%
$$

3. Total Pendapatan $\left(X_{3}\right)$

Total Pendapatan adalah jumlah seluruh pendapatan perbankan syariah.

4. BI Rate $\left(X_{4}\right)$

BI rate adalah tingkat bunga bank konvensional rata-rata

5. Tingkat bagi hasil adalah persentase pengembalian atas dana nasabah yang disalurkan melalui tabungan mudharabah.

NPF, FDR, total pendapatan, BI rate, dan tingkat bagi hasil dihitung dalam jangka waktu Januari Tahun 2011 sampai Juni Tahun 2014 yang terdapat dalam laporan publikasi Bank Umum Syariah pada website resmi Bank Indonesia.

\section{Populasi dan Sampel}

Populasi dalam penelitian ini adalah semua Bank Umum Syariah dan Unit Usaha Syariah yang terdaftar di Bank
Indonesia. Penelitian ini menggunakan metode pengambilan sampel jenuh. Sampel jenuh adalah teknik penentuan sampel bila semua anggota populasi digunakan sebagai sampel.

\section{Jenis dan Sumber Data}

Jenis data yang digunakan dalam penelitian ini merupakan data yang bersifat sekunder yang disusun secara time series dari bulan Januari 2011 sampai dengan bulan Juni 2014. Sumber data yang digunakan dalam penelitian ini diperoleh dari statistik perbankan syariah yang diterbitkan oleh Bank Indonesia melalui situs resmi Bank Indonesia: www.bi.go.id.

\section{Teknik Analisis}

Penelitian ini menggunakan analisis regresi linier berganda (Multiple Linier Regression Analysis).

\section{HASIL DAN PEMBAHASAN}

\section{Uji Normalitas}

Normalitas residual dapat diketahui dengan cara melihat grafik $\mathrm{P}-\mathrm{P}$ plot. Jika data menyebar di sekitar garis diagonal dan mengikuti arah garis diagonal maka model regresi memenuhi asumsi normalitas. Berikut adalah gambar normalitas data:

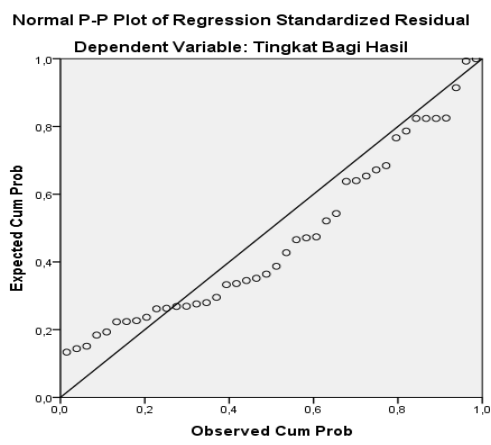

Sumber: Hasil Uji SPSS, 2015 
Gambar 2.

Grafik Normalitas P-P plot

Disamping itu normalitas dapat juga dipastikan dengan menggunakan uji Kolmogorov-Smirnov Test. Tujuannya adalah juga untuk mengetahui data berdistribusi normal atau tidak. Data dikatakan berdistribusi normal jika signifikansinya lebih dari 0,05.

Hasil perhitungan di bawah ini diperoleh nilai Kolmogorov Smirnov test sebesar 0,949 dengan tingkat signifikansi sebesar 0,329. Nilai signifikansi ini lebih besar dari 0,05 yang berarti data berdistribusi normal.

Berikut hasil tabel pengujian normalitas data selengkapnya :

Tabel 2.

Uji Normalitas

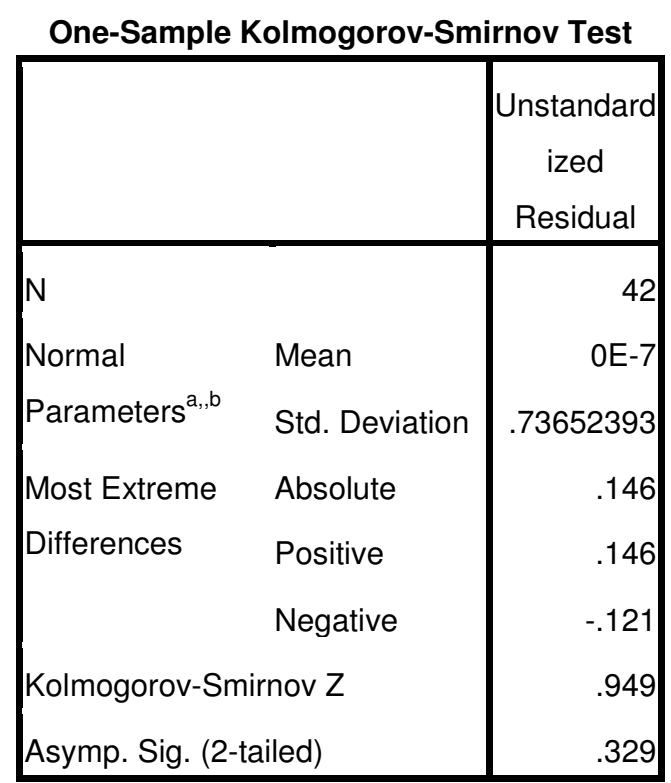

Sumber: Hasil Uji SPSS, 2015

\section{Uji Multikolinearitas}

Multikolinearitas berarti adanya hubungan linear yang sempurna atau pasti, diantara beberapa atau semua variabel yang menjelaskan dari model regresi. Untuk mendeteksi adanya gejala multikolinearitas pada model regresi diuji dengan menggunakan Variance Inflation Factor (VIF). Multikolinearitas terjadi apabila nilai VIF $\geq 10$. hasil pengujian multikolinearitas dalam penelitian ini ditunjukkan dalam tabel berikut ini :

Tabel 3.

Hasil Uji Multikolinearitas

\begin{tabular}{|l|l|l|}
\hline Variabel & VIF & Keterangan \\
\hline NPF & 2,617 & Bebas multikol \\
\hline FDR & 1,259 & Bebas multikol \\
\hline $\begin{array}{l}\text { Total } \\
\text { Pendapatan }\end{array}$ & 1,875 & Bebas multikol \\
\hline Bl rate & 2,494 & Bebas multikol \\
\hline
\end{tabular}

Sumber : Hasil Uji SPSS, 2015 (diolah)

Berdasarkan tabel diatas diketahui bahwa semua variabel bebas yaitu NPF $\left(X_{1}\right)$, FDR $\left(X_{2}\right)$, Total Pendapatan $\left(X_{3}\right)$, dan Bl rate $\left(X_{4}\right)$ mempunyai nilai $\mathrm{VIF}<10$. Hal ini dapat disimpulkan bahwa pada model regresi tidak terjadi Multikolinearitas.

\section{Uji Heteroskedastisitas}

Pengujian untuk heteroskedastisitas dilakukan untuk mengetahui ada tidaknya hubungan antar variabel penganggu dengan variabel bebasnya. Jika terjadi gejala homoskedastisitas pada model yang digunakan, berarti tidak terjadi hubungan antara variabel pengganggu dengan variabel bebas, sehingga variabel tergantung benar-benar hanya dijelaskan oleh variabel bebasnya. Uji gejala heterokedastisitas juga dapat diketahui dengan menggunakan scatter analisis. Jika titik - titik menyebar dan tidak membentuk pola yang khas maka uji 
regresi tidak terkena asumsi heteroskedastis. Berikut hasil selengkapnya

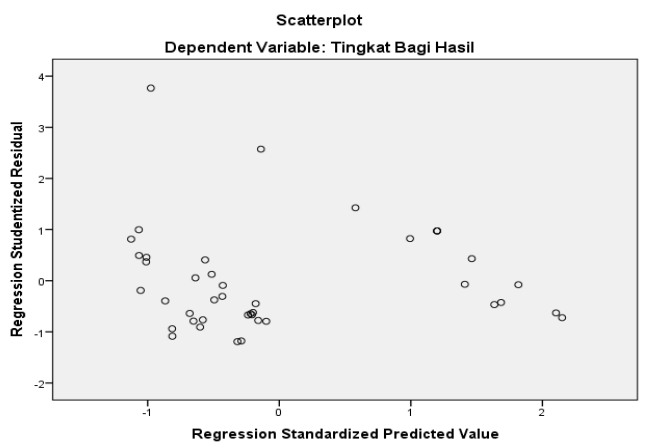

Sumber: Hasil Uji SPSS, 2015

\section{Gambar 3.}

Uji Heteroskedastisitas

Gambar diatas dapat dilihat bahwa titik - titik menyebar tidak membentuk pola yang khas dengan demikian dapat disimpulkan bahwa terjadi gejala homokedastis atau tidak terjadi hubungan antara variabel penggangu dengan variabel bebas, sehingga variabel tergantung benarbenar hanya dijelaskan oleh variabel bebas.

\section{Uji Autokorelasi}

Pengujian gejala autokorelasi ini digunakan untuk mengetahui ada tidaknya hubungan antar kesalahan pengamatan atau error residual. Untuk mengetahui ada tidaknya autokorelasi ini digunakan uji Durbin Watson. Tabel menunjukkan nilai Durbin Watson diperoleh nilai 1,757. Pengujian dikatakan bebas autokorelasi jika berada pada rentang du sampai 4 - du pada tabel Durbin Watson dengan jumlah variabel bebas $=4$, dengan $n$ sebesar 42. Pada tingkat kesalahan 0,05 dengan besar observasi diperoleh nilai du sebesar 1,7202. Sehingga rentang bebas autokorelasi adalah 1,3064 sampai dengan 2,2798. Sedangkan pada hasil perhitungan diperoleh nilai 1,757 yang berarti nilai Durbin Watson masih pada rentang daerah bebas autokorelasi.

\section{Koefisien Determinasi Berganda dan} Koefisien Korelasi Berganda

Koefisien determinasi menunjukkan seberapa besar kemampuan variabel independen terhadap variabel dependen. Bila semakin tinggi nilai R2 suatu regresi maka semakin baik.

Berikut hasil tabel mengenai koefisien determinasi berganda:

Tabel 4.

Hasil Koefisien Determinasi Berganda

Model Summaryb

\begin{tabular}{|c|c|c|c|c|c|}
\hline $\begin{array}{l}\text { M } \\
\text { od }\end{array}$ & $R$ & $\begin{array}{c}\mathrm{R} \\
\text { Squ } \\
\text { are }\end{array}$ & $\begin{array}{c}\text { Adjust } \\
\text { ed R } \\
\text { Squar } \\
e\end{array}$ & $\begin{array}{c}\text { Std. } \\
\text { Error of } \\
\text { the } \\
\text { Estima } \\
\text { te }\end{array}$ & $\begin{array}{c}\text { Durbin } \\
- \\
\text { Watso } \\
n\end{array}$ \\
\hline & $\begin{array}{r}.851 \\
a\end{array}$ & .724 & .694 & .77531 & 1.757 \\
\hline
\end{tabular}

a. Predictors: (Constant), BI rate, FDR, Total Pendapatan, NPF

b. Dependent Variable: Tingkat bagi hasil

Sumber: Hasil Uji SPSS, 2015

Pada Tabel 4. dapat dilihat bahwa nilai $R^{2}$ atau koefisien determinasi adalah sebesar 0,724, hal ini berarti bahwa perubahan variabel Tingkat Bagi Hasil Tabungan Mudharabah (Y) yang disebabkan oleh adanya NPF $\left(X_{1}\right), F D R$ $\left(X_{2}\right)$, Total pendapatan $\left(X_{3}\right), B$ rate $\left(X_{4}\right)$ 
adalah sebesar 0,724 atau $72,4 \%$ sedangkan sisanya sebesar 0,276 atau 27,6\% dipengaruhi oleh variabel lain diluar variabel bebas yang digunakan dalam penelitian. Nilai koefisien determinasi antara 0-1. Semakin mendekati 1 (100\%) artinya model sangat baik karena semua keragaman variabel independen dapat menjelaskan variabel dependen (Indriani, 2008 : 97). Jadi dapat disimpulkan bahwa penelitian ini sangat baik karena variabel $\operatorname{NPF}\left(X_{1}\right), \operatorname{FDR}\left(X_{2}\right)$, Total Pendapatan $\left(X_{3}\right)$, $B I$ rate $\left(X_{4}\right)$ dapat menjelaskan variabel Tingkat Bagi Hasil Tabungan Mudharabah (Y).

Disamping diketahui nilai koefisien determinasi $\left(R^{2}\right)$ juga diperoleh nilai koefisien korelasi (R). Pada tabel menunjukkan nilai R atau koefisien korelasi adalah sebesar 0,851, hal ini berarti bahwa NPF $\left(X_{1}\right), \operatorname{FDR}\left(X_{2}\right)$, Total Pendapatan $\left(X_{3}\right)$, $B$ rate $\left(X_{4}\right)$ secara bersama-sama berhubungan sangat kuat dengan Tingkat Bagi Hasil Tabungan Mudharabah (Y) dengan nilai koefisien sebesar 0,851 . Nilai $R$ merupakan multiple coefficient correlation. Nilai $R$ berkisar antara -1 sampai 1 . Jika nilai $R$ semakin mendekati - 1 atau 1 menunjukkan hubungan semakin kuat, jika nilai $R$ mendekati 0 menunjukkan hubungan semakin lemah (Indriani, 2008 : 97).

\section{Pengujian Hipotesis}

Untuk melakukan pengujian pengaruh variabel bebas secara bersama-sama dengan menggunakan teknik statistik uji-F. Hasil pengujian menunjukkan bahwa nilai uji $F$ adalah sebesar 24,251 dengan tingkat signifikansi 0,000 . Nilai signifikansi ini lebih kecil dari 0,05 sehingga dapat disimpulkan bahwa variabel NPF $\left(X_{1}\right), \operatorname{FDR}\left(X_{2}\right)$, Total Pendapatan $\left(X_{3}\right), \quad$ Bl rate $\left(X_{4}\right)$ secara bersama-sama berpengaruh secara signifikan terhadap Tingkat Bagi Hasil Tabungan Mudharabah. Yang berarti menerima $\mathrm{H}_{1}$ dan menolak $\mathrm{H}_{0}$. Setelah dilakukan pengujian dengan menggunakan uji $F$ maka langkah selanjutnya melakukan pengujian dengan uji $t$, karena apabila ada pengaruh secara bersama - sama maka sekurang kurangnya ada 1 variabel yang berpengaruh parsial. Uji T atau t-hitung didapat dari persamaan sebagai berikut :

$\mathrm{t}-$ hitung $=\frac{\text { koefisien regresi }}{\text { standar error }}$

Koefisien regresi adalah koefisien yang menunjukkan kemiringan atau signifikansi suatu persamaan, sedangkan standar error adalah nilai standar deviasi error dimana error adalah nilai duga dikurangi dengan nilai sebenarnya.

Untuk mengetahui apakah hasil pengujian secara parsial terdapat pengaruh secara signifikan, digunakan aturan pembacaan sebagai berikut :

1. Jika signifikansi uji † lebih kecil atau sama dengan 0,05 maka dapat disimpulkan bahwa NPF $\left(X_{1}\right)$, FDR $\left(X_{2}\right)$, Total Pendapatan $\left(X_{3}\right)$, Bl rate $\left(X_{4}\right)$ secara parsial berpengaruh secara signifikan terhadap Tingkat Bagi Hasil Tabungan Mudharabah. 
2. Jika signifikansi uji † lebih besar dari 0,05 maka dapat disimpulkan bahwa NPF $\left(X_{1}\right)$, FDR $\left(X_{2}\right)$, Total Pendapatan $\left(X_{3}\right)$, Bl rate $\left(X_{4}\right)$ secara parsial berpengaruh secara signifikan terhadap Tingkat Bagi Hasil Tabungan Mudharabah.

Adapun hasil dari Uji $T$ adalah sebagai berikut :

Tabel 5.

Hasil Uji T

\begin{tabular}{|l|l|l|}
\hline $\begin{array}{l}\text { Variabel } \\
\text { Terikat }\end{array}$ & t-hitung & Signifikan \\
\hline Konstanta & $-2,914$ & 0,006 \\
\hline NPF & $-3,299$ & 0,002 \\
\hline FDR & 1,314 & 0,197 \\
\hline $\begin{array}{l}\text { Total } \\
\text { Pendapatan }\end{array}$ & $-1,037$ & 0,306 \\
\hline Bl rate & 7,811 & 0,000 \\
\hline
\end{tabular}

Sumber : hasil uji SPSS, 2015 (diolah)

Berdasarkan tabel 5 terlihat bahwa variabel NPF dan BI rate menghasilkan tingkat signifikansi kurang dari 5\% dengan demikian dapat disimpulkan bahwa NPF $\left(X_{1}\right)$ dan $B I$ rate $\left(X_{4}\right)$ berpengaruh signifikan secara parsial terhadap Tingkat Bagi Hasil Tabungan Mudharabah (Y). Sedangkan variabel FDR $\left(X_{2}\right)$ dan Total Pendapatan $\left(X_{3}\right)$ menghasilkan tingkat signifikansi lebih dari 5\%. Dengan demikian, dapat disimpulkan bahwa FDR $\left(\mathrm{X}_{2}\right)$ dan Total Pendapatan $\left(X_{3}\right)$ secara parsial tidak berpengaruh signifikan terhadap Tingkat Bagi Hasil Tabungan Mudharabah (Y).

\section{Pembahasan}

Menurut pengujian asumsi klasik yang dilakukan pada variabel-variabel penelitian ini, ridak ditemukan data yang bias. Uji normalitas menunjukkan bahwa variabel-variabel dalam penelitian mempunyai distribusi normal. Uji multikolinearitas yang dilakukan tidak ada hubungan antara masing-masing variabel, hal ini membuktikan bahwa bebas dari multikolineritas. Pada uji autokorelasi, nilai durbin watson berada diatas nilai du sehingga menunjukkan bebas dari autokorelasi positif maupun negatif atau tidak ada korelasi antar variabel. Uji heterokedastisitas tidak terdapat hubungan antar variabel dependen dan variabel independen, sehingga bebas dari heterokedastisitas.

Berdasarkan hasil uji statistik dapat diperoleh persamaan regresi linear berganda untuk periode 2011-2014, adalah sebagai berikut :

$Y=-8,981-1,567 X 1+0,038 \times 2-2,2727 E-$

\section{$005 \times 3+2,150 \times 4$}

Dari persamaan di atas dapat diketahui bahwa setiap kenaikan satu satuan NPF (X1) maka tingkat bagi hasil tabungan mudharabah akan turun sebesar 1,567. Hal ini menunjukkan bahwa dengan semakin meningkatnya NPF maka akan menurunkan tingkat bagi hasil tabungan mudharabah. Setiap kenaikan satu satuan FDR (X2) maka tingkat bagi hasil tabungan mudharabah akan naik sebesar 0,038. Hal ini menunjukkan bahwa dengan semakin meningkatnya FDR maka tingkat bagi hasil tabungan mudharabah mengalami kenaikan. Setiap kenaikan satu satuan Total Pendapatan (X3) maka 
tingkat bagi hasil tabungan mudharabah akan turun sebesar 2,272E-005. Hal ini menunjukkan bahwa dengan semakin meningkatnya total pendapatan maka akan menurunkan tingkat bagi hasil tabungan mudharabah. Setiap kenaikan satu satuan BI rate (X4) maka tingkat bagi hasil tabungan mudharabah akan naik sebesar 2,150. Hal ini menunjukkan bahwa dengan semakin meningkatnya $\mathrm{Bl}$ rate maka tingkat bagi hasil tabungan mudharabah mengalami kenaikan.

Pengaruh NPF secara Parsial Terhadap Tingkat Bagi Hasil Tabungan Mudharabah

Nilai uji $\dagger$ variabel NPF adalah sebesar -3,299 dengan tingkat signifikansi 0,002 . Nilai signifikansi uji t ini lebih kecil dari 0,05 . Oleh karena signifikansi dibawah 0,05 maka dapat disimpulkan bahwa NPF berpengaruh signifikan negatif terhadap tingkat bagi hasil tabungan mudharabah, sehingga Ho ditolak.

Menurut Djamil (2014 : 66) bahwa dalam statistik perbankan syariah yang diterbitkan oleh Direktorat Perbankan Syariah Bank di Indonesia dapat dijumapi istilah Non Performing Financing (NPF) yang diartikan sebagai pembiayaan non lancar mulai dari kurang lancar sampai macet. Pembiayaan bermasalah tersebut, jika ditinjau dari segi produktivitasnya berkaitan dengan kemampuan menghasilkan pendapatan bagi bank, sudah berkurang atau menurun dan bahkan mungkin tidak ada lagi. bahkan dari segi bank, sudah tentu mengurangi pendapatan, memperbesar biaya pencadangan, yaitu PPAP (Penyisihan Penghapusan Aktiva Produktif), sedangkan dari segi nasional, mengurangi kontribusinya terhadap pembangunan dan pertumbuhan ekonomi.

Secara teori bahwa Non performing financing (NPF) akan berdampak pada menurunnya tingkat bagi hasil yang dibagikan pada pemilik dana. Hal ini sejalan dengan penelitian ini. Penelitian ini menerangkan bahwa setiap kenaikan satu satuan NPF (X1) maka tingkat bagi hasil tabungan mudharabah akan turun sebesar 1,567. Hal ini menunjukkan bahwa dengan semakin meningkatnya NPF maka menurunkan tingkat bagi hasil tabungan mudharabah. Jadi dapat disimpulkan bahwa semakin meningkatnya NPF maka akan menurunkan tingkat bagi hasil tabungan mudharabah. Hal ini dikarenakan NPF menurunkan pendapatan bank syariah sehingga tingkat bagi hasil tabungan mudharabah mengalami penurunan.

\section{Pengaruh FDR secara Parsial Terhadap} Tingkat Bagi Hasil Tabungan Mudharabah

Nilai uji $\dagger$ variabel FDR adalah sebesar 1,314 dengan tingkat signifikansi 0,197 . Nilai signifikansi uji $t$ ini lebih besar dari 0,05 . Oleh karena signifikansi diatas 0,05 maka dapat disimpulkan bahwa FDR berpengaruh tidak signifikan terhadap tingkat bagi hasil tabungan mudharabah, sehingga Ho diterima.

Kondisi internal bank syariah bergantung kepada dana pihak ketiga. Dana pihak ketiga merupakan salah satu 
faktor untuk menentukan bagi hasil (Antonio, 2001 : 139). Salah satu ketentuan yang dipakai untuk menentukan perolehan jumlah dana pihak ketiga adalah dengan FDR (Financing to Deposit Ratio). FDR adalah rasio pembiayaan yang diberikan kepada pihak ketiga dalam rupiah maupun valuta asing.

Dalam penelitian ini FDR dikatakan tidak signifikan, artinya bahwa dalam menentukan tingkat bagi hasil tabungan mudharabah, FDR tidak menjadi acuan dalam menentukan tingkat bagi hasil tabungan mudharabah. Hal ini dikarenakan bahwa variabel FDR tidak bisa diprediksi untuk menentukan tingkat bagi hasil tabungan mudharabah dan terdapat faktor penganggu lainnya yang mempengaruhi variabel FDR. Salah satunya adalah faktor manajemen pembiayaan bank syariah. Manajemen pembiayaan bank syariah berperan pada bank syariah untuk menyediakan dana guna membiayai kebutuhan nasabah yang memerlukan dan layak memperolehnya (Arifin, 2009 : 233).

Pengaruh Total Pendapatan secara Parsial Terhadap Tingkat Bagi Hasil Tabungan Mudharabah

$\begin{array}{cccc}\text { Nilai } & \text { uji } \dagger & \text { variabel } & \text { total } \\ \text { pendapatan } & \text { adalah } & \text { sebesar } & -1,037\end{array}$ dengan tingkat signifikansi 0,306. Nilai signifikansi uji $t$ ini lebih besar dari 0,05. Oleh karena signifikansi diatas 0,05 maka dapat disimpulkan bahwa total pendapatan berpengaruh tidak signifikan terhadap tingkat bagi hasil tabungan mudharabah, sehingga Ho diterima.

Total pendapatan bank terdiri dari pendapatan operasional, pendapatan operasi utama bank syariah, pendapatan operasional lainnya, pendapatan non operasional, dan bagi hasil investasi tidak terikat. Dana yang diperoleh bank syariah dialokasikan untuk menghasilkan pendapatan kemudian didistribusikan kepada para nasabah.

Dalam penelitian ini total pendaptan dikatakan tidak signifikan, artinya bahwa dalam menentukan tingkat bagi hasil tabungan mudharabah, total pendapatan tidak menjadi acuan dalam menentukan tingkat bagi hasil tabungan mudharabah. Hal ini dikarenakan data total pendapatan yang diambil dari laporan perbankan syariah bersifat akrual bukan cash basis. Menurut Wiroso (2011 : 24) menyatakan bahwa asumsi dasar dari akrual yang dipergunakan dalam penyusunan laporan keuangan syariah, sedangkan pendapatan yang dipergunakan sebagai dasar perhitungan pembagian hasil usaha kepada pemilik modal mudharabah adalah pendapatan yang nyata-nyata diterima (cash basis). Tujuannya untuk memberikan informasi yang lengkap kepada pengguna laporan keuangan dalam melakukan analisa yang dilakukan oleh Lembaga Keuangan Syariah dan kebutuhan analisa laporan kevangan lainnya.

Pengaruh BI rate secara Parsial Terhadap Tingkat Bagi Hasil Tabungan Mudharabah 
Nilai uji $\dagger$ variabel $\mathrm{Bl}$ rate adalah sebesar 6,916 dengan tingkat signifikansi 0,000 . Nilai signifikansi uji t ini lebih kecil dari 0,05 . Oleh karena signifikansi dibawah 0,05 maka dapat disimpulkan bahwa BI rate berpengaruh signifikan terhadap tingkat bagi hasil tabungan mudharabah, sehingga Ho ditolak.

Menurut Bank Indonesia pengertian dari $\mathrm{Bl}$ Rate adalah suku bunga kebijakan yang mencerminkan sikap atau stance kebijakan moneter yang ditetapkan oleh bank Indonesia dan diumumkan kepada publik. Penelitian ini signifikan positif karena adanya motivasi manajemen bank syariah dengan cara menghindari risiko di perbankan syariah. Risiko yang dihindari bank syariah adalah displaced commercial risk. Displaced commercial risk merupakan transfer risiko yang berhubungan dengan pemegang saham (Usman, 2012 : 296). Wahyudi (2012) menjelaskan bahwa dengan adanya displaced commercial risk maka bank syariah mempunyai kemampuan untuk mengenali karaeristik pemilik dana dan mengukur sensitivitasnya terhadap return perbankan konvensional. Hal ini mengakibatkan adanya standar praktik yang dikembangkan untuk menghindari penarikan dana tersebut. Saah satunya dengan menggunakan profit equalization reserve (PER). Pemberlakuan PER, bank syariah dapat menjaga pembayaran kepada investor kepada investor tetap berada pada level pasar. PER yang diakumulasikan tersebut sebenarnya ekuitas dari investor pemegang saham dapat ditarik kemudian untuk meratakan tingkat bagi hasil ketika tingkat bagi hasil dari sebuah investasi turun dan ketika akumulasi PER tidak mencukupi dalam memberikan tingkat bagi hasil yang sama dengan suku bunga pasar, bank syariah dapat memberikan porsi pendapatan bank syariah kepada nasabah.

Pengaruh NPF, FDR, Total Pendapatan, dan BI rate Secara Simultan Terhadap Tingkat Bagi Hasil Tabungan Mudharabah

Berdasarkan pada hasil uji F, dapat diketahui bahwa NPF, FDR, Total Pendapatan, dan Bi rate secara simultan menghasilikan positif signifikan dengan tingkat signifikan lebih kecil dari $5 \%$ yaitu sebesar 0,000 yang berarti bahwa NPF, FDR, Total Pendapatan, dan Bi rate memiliki pengaruh terhadap tingkat bagi hasil tabungan mudharabah. artinya bahwa keempat variabel independen tersebut dapat digunakan untuk menjelaskan prediksi untuk menentukan tingkat bagi hasil tabungan mudharabah bank syariah secara bersama-sama. Hal ini sesuai dengan pernyataan dan hasil penelitian yang dilakukan oleh Shiddia (2009) bahwa tingkat bagi hasil dipengaruhi oleh faktor internal dan faktor eksternal yang dijelaskan oleh NPF, FDR, dan total pendapatan untuk faktor internal dan BI rate untuk faktor eksternal.

\section{SIMPULAN}

\section{Simpulan}


Berdasarkan hasil analisis dan pengujian hipotesis, maka dapat diambil kesimpulan sebagai berikut :

1. Non Performing Financing (NPF) $\left(X_{1}\right)$ dan BI rate (X4) secara parsial berpengaruh signifikan terhadap tingkat bagi hasil tabungan mudharabah, sedangkan Financing to Deposit Ratio (FDR) $\left(\mathrm{X}_{2}\right)$ dan Total Pendapatan $\left(X_{3}\right)$ secara parsial tidak berpengaruh signifikan terhadap tingkat bagi hasil tabungan mudharabah.

2. Non Performing Financing (NPF), Financing to Deposit Ratio (FDR), Total Pendapatan, dan $\mathrm{Bl}$ rate secara simultan berpengaruh signifikan positif terhadap tingkat bagi hasil tabungan mudharabah dengan tingkat signifikansi sebesar 0,000 yang artinya bahwa keempat variabel tersebut dapat digunakan untuk menjelaskan prediksi untuk menentukan tingkat bagi hasil tabungan mudharabah secara bersama-sama.

Berdasarkan pernyataan tersebut disimpulkan bahwa secara keseluruhan variabel yang mempengaruhi tingkat bagi hasil tabungan mudharabah industri perbankan syariah di Indonesia periode 2011-2014 adalah variabel Non Performing Financing (NPF) dan Bl rate.

\section{Saran}

Berdasarkan kesimpulan di atas, saran yang dapat disampaikan dalam penelitian ini adalah :

1. Untuk Masyarakat
Investor atau calon investor disarankan untuk mengamati perkembangan kinerja internal perbankan syariah di Indonesia terutama NPF dan mengikuti perkembangan keadaan makro ekonomi terutama $\mathrm{Bl}$ rate karena berpengaruh terhadap tingkat bagi hasil tabungan mudharabah perbankan syariah di Indonesia.

2. Untuk Penelitian Selanjutnya

Selain Non Performing Financing (NPF), Financing to Deposit Ratio (FDR), Total Pendapatan, dan Bl rate masih banyak lagi variabel lain yang bisa diteliti untuk menilai variabel lain yang mempengaruhi tingkat bagi hasil tabungan mudharabah. Sehingga perlu dipertimbangkan untuk penggunaan variabel lain yang bisa mempengaruhi tingkat bagi hasil tabungan mudharabah perbankan syariah di Indonesia.

\section{DAFTAR PUSTAKA}

Antonio, Muhammad Syafi'i. 2001. Bank Syariah dari Teori ke Praktik. Jakarta: Gema Insani

Arifin, Zainul. 2009. Dasar-dasar Manajemen Bank Syariah. Jakarta : Azkia Publisher

Bank Indonesia. 2014. Moneter : BI rate, Januari 2011-Juni 2014. (Online), (http://www.bi.go.id/id/moneter/birate/data/Default.aspx, diakses tanggal 31 Agustus 2014) 
2014. Statistik Perbankan

Syariah, Januari 2011-Juni 2014. (Online),

(http://www.bi.go.id/id/statistik/perb ankan/syariah/Default.aspx, diakses tanggal 31 Agustus 2014)

Departemen Agama,RI. 2010. Al-Quran Tajwid dan Terjermahan. Jawa Barat: CV Penerbit Diponegoro

Djamil, Faturrahman. 2014. Penyelesaian Pembiayaan Bermasalah di bank Syariah. Jakarta : Sinar Grafika

Machmud, Amir dan Rukmana. 2010. Bank Syariah Teori, Kebijakan, dan Studi Empiris di Indonesia. Jakarta : Erlangga

Mawardi, Nasrah. 2005. "Faktor-faktor yang Mempengaruhi Penetapan Retun Bagi Hasil Deposito Mudharabah Mutlaqah Studi Kasus pada Unit Usaha Syariah Bank X" dalam Tesis. Jakarta : Universitas Indonesia

Muhamad. 2004. Teknik Perhitungan Bagi Hasil dan Pricing di Bank Syariah. Yogyakarta: UII Press

Shiddiq, Abu Bakar. 2009. "Pengaruh Jumalh Pendapatan, Penyaluran, Tabungan, Nisbah, dan $\mathrm{Bl}$ Rate Terhadap Tingkat Imbal Bagi Hasil Nasabah dengan Skim Mudharabah (Studi Kasus pada PT. Bank Muamalat Indonesia)" dalam Skripsi. Jakarta : UIN Syarif Hidayatullah

Sudarsono,Heri. 2008. Bank dan Lembaga Kevangan Syariah Deskripsi dan Ilustrasi. Yogyakarta : EKONISIA
Usman, Rachmadi. 2012. Aspek Hukum perbankan syariah di Indonesia. Jakarta : Sinar Grafika

Vustany, Roci Octaviano. 2006. "Faktorfaktor yang Mempengaruhi Pemberian Bagi Hasil Nasabah (Studi Kasus di Bank Muamalat Indonesia)" dalam Tesis. Jakarta : Universitas Indonesia

Wahyudi, Hidayat. 2012. Profit Equalization Reserve (PER) dan Investment Risk Riserve (IRR) dan (Idealisme) Ber Bank Syariah. (artikel Online), (http://ekonomi.kompasiana.com/bi snis/2012/04/13/profit-equalizationreserve-per-dan-investment-riskreserve-irr-dan-idealisme-ber-banksyariah-454257.html diakses 29 desember 2014)

Wiroso. 2005. Penghimpunan Dana dan Distribusi hasil Usaha Bank Syariah. Jakarta : Grasindo . 2011. Akuntansi Transaksi Syariah. Jakarta : Ikatan Akuntan Indonesia. 